\title{
A GAY WOMAN'S EXPERIENCES DURING HER CAREER IN THE DEPARTMENT OF DEFENCE PART: 1 - FLEET OF HOPE
}

\author{
BENEDICTOR LEAH TLOU \\ WILLEM SCHURINK \\ Programme in Leadership in Performance and Change \\ In the Department of Human Resource Management \\ Rand Afrikaans University
}

\begin{abstract}
A are opportunity presented itself to undertake an explorative qualitative study of the perceptions and experiences of an authentic lesbian who was for some time an employee of the South African Department of Defence (DOD). In order to capture, describe and reach an understanding of this woman's experiences and worldviews, we employed a qualitative methodology, i.e. with her assistance an autobiographical sketch was constructed, and utilizing a variant of analytic induction (AI) and symbolic interactionism, we analysed and interpreted the material.

According to qualitative requirements we provide in this article an account of the major steps taken during the execution of the case study. Following the Lowney-Winslows AI approach (1981), we are convinced that our study provided one real case, which enhanced our intuitive understanding of lesbians working in the South African Defence Force. It namely served as a starting point for further research that could carry our case study on to a more formal implementation of AI, and particularly the execution of steps five through to seven.

We feel convinced that the study was ethically properly and scientifically correctly executed and that it enabled us to obtain valuable and rich information on lesbianism and the South African military.

For the benefit of the reader we present Thando's entire narrative.
\end{abstract}

\section{OPSOMMING}

'n Unieke geleentheid het hom voorgedoen om 'n ekploratiewe kwalitatiewe studie van die persepsies en ervarings van 'n outentieke lesbiër wat vir 'n tyd lank werksaam was by die Suid-Afrikaanse Departement van Verdediging, te onderneem. Ten einde die vrou se ondervindings en wêreldbeskouings vas te vang, te beskryf en 'n begrip daarvan op te bou, het ons 'n kwalitatiewe methodology benut, dit is, met die samewerking van die vrou, is 'n outobiografiese skets gekonstruuer, en het ons 'n vorm van analitiese induksie en simboliese interaksionisme benut. Ooreenkomstig die vereistes vir kwalitatiewe navorsing verskaf ons in hierdie artikel 'n uiteensetting van die vernaamste stappe wat in die uitvoer van die studie geneem is. In navolging van die Lowney-Winslows AI benadering (1981), is ons daarvan oortuig dat die studie een ware geval daarstel wat 'n spontane begrip van lesbiërs in die SuidAfrikaanse Weermag aanmoedig. Dit dien naamlik as ' $n$ beginpunt vir verdere navorsing wat hierdie gevallestudie na 'n meer formele implementering van AI, en in die besonder, die uitvoering van stappe 5 tot 7 kan neem.

Ons voel oortuig daarvan dat die studie eties behoorlik en wetenskaplik verantwoordelik van staple gestuur is en dat dit ons waardevolle en ryke inligting omtrend lesbinisme en die Suid-Afrikaanse weermag bied.

Vir die gerief van die leser word Thando se volledige verhaal aangebied.

Many members of the public as well as members and employees in the military still see homosexual behaviour as incompatible with military service and a threat to the combat effectiveness of the military. People who are homosexual have been treated differently in most of the armed forces globally. Bell and Binnie (2002) writing on the gays and the military debate believe that the relationship between this debate and the wider question of sexual citizenship needs to be examined. They continue:

At its simplest, of course, the argument is that denying homosexuals the right to fight for their country denies them full citizenship, given the continuing durability of the relationship between the citizen and the nation-state. This obviously sidesteps the crucial question of the legitimacy of such a strategy in the context of rights agitation. In the same manner as the debate on lesbian and gay marriage, the gays in the military debate is upheld by some as having a destabilizing, radical function: opening up one of the most heteronormative state institutions to homosexuals begins the task of undermining heteronormativity itself (emphasis added)(Bell \& Binnie, 2002, p. 455).

When South Africa became a democratic country in 1994, a new Constitution was introduced which is regarded as one the most liberal in the world. The Bill of Rights that is contained in chapter two of the Constitution, is the cornerstone of democracy in South Africa. It enshrines the rights of all people,

Requests for copies should be addressed to: BL Tlou, Department of Human Resource Management, RAU University, PO Box 524, Auckland Park, 2006 including homosexuals, in our country and affirms the democratic values of human dignity, equality and freedom. According to the clause on equality, Section 9 (3), "...the state may not unfairly discriminate directly or indirectly against anyone on one or more grounds, including race, gender, sex, pregnancy, marital status, ethnic or social origin, colour, sexual orientation, age, disability, religion, conscience, belief, culture, language and birth".

It goes without saying that South African Government Departments including the Department of Defence (DOD) had to align its departmental policies with the Constitution of the country. The Department of Defense consequently drafted a Code of Good Employment Practice regarding Sexual Orientation in the Workplace. The policy is now at an advanced stage of drafting and inputs are currently been awaited from local Non-Governmental Organizations such as the Gay and Lesbian Equality Project.

The South African military stands in sharp contrast to the military in both the USA's and the UK's ruling: “don't ask, don't tell. The South African Department of Defense acknowledges that homosexual people are an integral part of South African society and that they are only different in terms of their sexual preference. The DOD also acknowledges that as an employer, it has members and employees of all sexual orientations. The DOD's Code of Good Employment Practice does not make any value judgment in this regard, but accepts differences in sexual orientation as a given. The Code of Good Employment Practice 
Conduct regarding Sexual Orientation in the Workplace was drafted specifically to combat discrimination based on members' sexual orientation in the Department.

In 2000 the Chief Directorate Equal Opportunities in conjunction with the Centre conducted a study on the attitudes and perceptions of the DOD population regarding the integration of gays and lesbians among its personnel for Effect Analysis. The research results gained by this quantitative study indicated substantial prejudice and stereotypes with regard to gays and lesbians in the Department. On eight of the ten statements contained in the questionnaire, the sample responded negatively in respect of the integration of gays and lesbians in the DOD. Exceptions were respondents of the office of the Secretary for Defence and to some extent respondents of the South African Military Health Service (SAMHS). The latter two sub-groups were inclined to hold more positive attitudes regarding the integration of gays and lesbians. The general conclusion reached was that the respondents appear to be very divided on issues related to the integration of gays and lesbians in the Department. These research results indicated the need for a DOD code of good practice regarding sexual orientation in the workplace, which was subsequently drafted.

The results of this study were also presented at the 4th Biennial Equal Opportunity Research Symposium held from 5-6 December 2001 at Cocoa Beach in Florida, USA. Issues that were raised centred on the question of the negative perceptions held by most of the African population and the more positive responses by the Asian population of the DOD regarding the integration of gays and lesbians. Recommendations were made and one of them was to undertake a follow-up study in the form of focus groups in order to explore qualitatively the negative perceptions that prevail regarding the integration of gays and lesbians in the Department.

While research on African and Asian members of the DOD regarding their views on gays and lesbians is very important and must certainly receive attention, a rare opportunity presented itself to undertake a qualitative study of the perceptions and experiences of one former white female gay employee of the DOD. This opportunity implied that we could learn first-hand of the experiences a gay woman, who worked for some time at the DOD, had. More specifically, an opportunity presented itself to discover and describe how such people experience and handles the behaviour and perceptions of their heterosexual colleagues towards them. Finally, there is a scarcity of scientific knowledge on homosexual/lesbian work1, and particularly the careers of gay women in the South Africa's military.

While Tlou discussed the proposed research with a colleague, he mentioned that he knows a gay female staff member of the DOD who would be keen to participate in a research project. We discussed this opportunity and decided that Tlou would contact the female employee, which she did. The woman indicated that she was indeed interested in participating in the study.

\section{AIM}

This article is based on an in-depth study of one white gay female employee's experiences and views of her homosexuality while she was working at the DOD. The objective is to gain a better understanding of the problems facing gay female employees of the DOD.

\section{RESEARCH METHODOLOGY}

In order to capture, describe and finally reach an understanding of the lesbian's experiences during her career in the Department of Defense, a qualitative methodology was used.

\section{CONTACT WITH GAY WOMEN}

Tlou met the first potential research participant to be known as Lindi through one of her male colleagues that was on a military course with her. As they shared and talked about the work schedule and the studies, he became interested in her MA study. He then explained to her that if there is a need to interview or talk to a lesbian, he is ready to introduce her to a friend who would be willing to assist her. He made the initial contacts and provided Tlou with his friend's contact telephone numbers. Tlou talked to Lindi over the phone and they made an appointment to meet at Lindi's home. On 14 June 2002 Tlou met Lindi, her partner and her mother and after explaining the purpose of the survey Lindi was prepared to be involved with the study.

Lindi is a white lesbian in the service of the Department of Defence. She is a very friendly person, kind and outspoken. She and her family gave Tlou a warm welcome and Tlou felt at ease and home. Tlou's general impression of the family was that they are kind and respectable people. When she was at Lindi's place other family members as well as another gay couple came to visit and Tlou was also introduced to them. She felt quite comfortable and they invited her to join them for supper.

\section{ENTERS THANDO}

Tlou and Lindi arranged to meet again on 2 July 2002 at $18 \mathrm{~h} 00$ and also agreed to communicate via e-mail. On 24 June Tlou received an e-mail whereby the research participant raised a concern regarding the study. When they met on 2 July she indicated that she felt that she was not the right person to assist Tlou with her study since she has never had any personal experiences that she can write about because she was still "in the closet", i.e. concealed her homosexuality. She further indicated that she knew someone who had negative experiences and who might be willing to assist with the study. Tlou then agreed to be introduced to the second research participant so as to determine if she would be willing to assist with the proposed study.

Lindi made contact with the second research participant to be known as Thando and she arranged for the two of them to meet. They made the initial contact via e-mail and telephonically and thereafter Lindi, Thando and Tlou met on 7 August 2002. Tlou was introduced to Thando and explained the purpose of the study to her. After Tlou answered the few questions Thando had, she agreed to assist with the study. She agreed to write a sketch and promised to have the first draft ready on 17 August 2002. Thando is a white lesbian who is confident and outspoken and she seemed very friendly from our their first contact. She worked for the Department of Defence for more than 10 years and left the service three years ago.

The first draft of the sketch was received as arranged. After an email discussion with Schurink, further questions and clarifications were forwarded to Thando. On 22 August Tlou met Thando again and handed over information that was still required from her and she promised to have the report ready on 9 September 2002. During this meeting it was agreed that some detailed information would not be divulged since it may reveal Thando's identity and have some repercussions for some of her friends who still serves in the DOD. Thando also requested that the sketch should not be published in any DOD magazine since her story may jeopardise her friends who are serving in the Department and are still in the closet. The material obtained from this research should therefore be used for study purposes only. Thando was re-assured that her identity would be kept confidential. Thereafter Thando and Tlou kept contact through e-mail correspondence. The final report was received on 12 September 2002.

As we already indicated Thando's sketch forms the basis of the article. But how credible is this story? This is the question we now turn to. 


\section{CREDIBILITY OF THANDO'S SKETCH}

In order to assist the reader to assess Thando's account we generally followed the guidelines provided by Howard Becker (1970) on establishing the credibility of case studies as well as more recent ideas on the trustworthiness of qualitative research in ensuring a quality study. The following were the key decisions we took:

First, as already pointed out the substantive, question we had to address was: How does one authentic lesbian manage her military career?

Second, and flowing from the former question, our epistemological approach was that we wanted to generate, "subjective, soft" data in order to come to a interpretive understanding of lesbianism and military work in the South African context. Therefore, as already indicated, we opted for a qualitative methodology. That is why we request Thando to compile an essay briefly reviewing her total gay life but focusing on her career in the military. We did not proceed with any particular theory of lesbian work. Nevertheless, after having received Thando's sketch, we did examine particular theoretical ideas about lesbianism in our attempt to make sense of it. While our analysis reflect some aspects of grounded theory (Glaser \& Strauss, 1967), we feel that in general our approach is more in line with analytic induction (AI). But what does $\mathrm{AI}$ implies?

Manning (1991, p. 405) writes:

Analytic induction seeks to develop universal statements containing the essential futures of a phenomenon, or those things that are always found to cause or lie behind the existence of a social occurrence. The essential features are revealed, it is argued, when they are always present when the phenomenon is present; when they are absent, the phenomenon is itself absent. The definitional aspect of science is critical in analytic induction, and in the procedure redefinition and reconceptualization are often required to narrow the range of applicability or the scope of the theory. Exceptions or negative cases assume a major significance, since the explanations aim for completeness and universality. Traditionally, only a few selected cases are subjected to careful scrutiny (persons and families have been used). (Emphasis in the original.)

He continues by describing 7 specific steps formalized by Cressey (1953) and concludes:

In Cressey's statement we discover the core features of the method as practiced: definition, tentative explanation, possible reformulation, and generalization. As he implies, the process may continue until a point of closure is achieved. This point is not defined in a straightforward manner (Manning, 1991:408-409).

Gill and Johnson (2002, p. 157) have the following to say:

In sum, AI and analogous theory-building approaches ostensibly seek to capture aspects of the social world from the perspective of actors and allow the revision of hypotheses and conceptual structures through the analysis and elimination of negative cases. In doing so it attempts to maintain faithfulness to empirical data gathered from a relatively small number of cases (emphasis added).

Though our work bears a close connection to AI, specific features of our approach that we need to emphasise, include:

i) We focused on one lesbian's views about her life in the South African Defence Force.

ii) We did not formalize specific hypotheses regarding lesbianism or lesbian work before the data were collected and did not formally examine or "test" any hypotheses drawn from the literature

iii) We do provide a commentary in a subsequent article, in the light of a general sociological approach to lesbianism as well as of some ideas of scholars on homosexuality and the military, and propose some ideas with an eye to reformulation. Following the Lowney-Winslows AI approach (1981), we feel our study provided one real case, which enhanced our intuitive understanding of lesbians working in the South African Defence Force. It served as a starting point for further research that could carry our case study on to a more formal implementation of AI, and particularly the execution of steps five through to seven.

Third, and following from our usage of AI, we made use of the symbolic interactionist perspective in which $\mathrm{AI}$ is embedded. We explain this perspective in greater detail below.

Fourth, in how human documents could be constructed, we noted that there are many different ways in which a person could express his/her personal life (cf. Plummer, 2001). Since we needed a human document, which would focus on a particular aspect of a woman's life, namely how she as a South African white lesbian experienced her career in the defence force and one, which, at the same time would provide us with some sense of her overall life, we decided upon the topical life document. While we do not want to claim that the document that was finally constructed could be placed on the same shelf as such well-known classic life history documents as Stanley 's delinquent life (Shaw, 1966), or Bogdan's (1974) study of Jane Fry's transsexuality, we are convinced that it represents a topical life document that provides a rather vivid description of Thando's experiences of her military career and her gay life. In sum: The data collection method utilised in the study was an autobiographical sketch. We are convinced that by using a life sketch or a combination of two autobiographies, i.e. topical autobiography and edited biography, we generated a comprehensive account of a local white lesbian's experiences as a former employee of the South African Department of Defense.

Fifth, we edited Thando's life history in the sense of Tlou asking her questions, and by requesting her to elaborate or clarify certain aspects in her story that were not clear to us. She was able to respond to almost all the questions except where she had indicated that such information might compromise the identity of some of her colleagues and friends still serving in the DOD.

Sixth, while ethics are particularly problematic in qualitative research including life history research emphasizing the flux and ever changing nature of human behaviour, we believe that we attended reasonably adequately to this. By employing pseudonames and deleing certain pieces that contained identifiable information we tried to ensure that neither Thando nor anybody that she wrote about could be revealed when academics read the sketch/article. Of course, while these tactics could make the risk of identification less likely, it can never be regarded as full proof. Regarding hurt and harm, we tried as far as is reasonable to prevent that the writing of her story for academically purposes would cause Thando harm or traumatize her. While Thando did not make mention of any uncomfortably she had when writing her story, it might have occurred and that Thando for some reason did not reveal it to us. Another related aspect, is that of exploitation. Since Thando's real identity had to remain confidential she did not gain any status for her account. Finally, the fact that we requested Thambo to write about her life, contributed to her life being changed. Plummer (2001) describe this dilemma as follows:

To speak traumas hitherto unnamed - of child abuse, of rape, of holocaust survival, of undiagnosed illness, of coming out as a transvestite - is to solidify and consolidate in words a kind of a life. And for this - in a way - the researcher becomes responsible.

Seventh, Thando and us signed an informant consent form, thus indicating that she undertook the research voluntarily, that her identity, would be kept confidential and that neither her name 
or anybody else's, nor any identifiable information would occur in the research articles we would compile.

Eight, in light of the discovery of "life story scandals" or studies accused of treacherous and untrustworthy (cf. Plummer 2001), we tried within the length limitation of this article, to account as fully as possible how the study was executed.

Ninth, while life history research can certainly not easily involved deceptions, we did ensure that Thando had absolute clarity of what our research interests were and what we wanted her to do.

Tenth, we employed what has became known as member checks, i.e. to get people acquainted or related to the research participant or sketch writer, to check on the factual correctness of the story. In this study, we were able to control the intern validity of the life history after, Thando, at our request, handed her story to a person that checked her account.

Finally, we employed what Plummer (1983) autocritique, i.e. we asked Thando herself to check the final version of her life sketch. She studied the draft article in order to ensure that her viewpoints and experiences were not interpreted out of context as well as to ensure that it did not contain any information that could reveal her identity and hurt her in any way. The draft, edited version of the sketch was e-mailed to her and she signed an agreement permitting us to use the sketch for scientific purposes.

We now present a brief discussion of the theoretical perspective, symbolic interactionism, which, as already mentioned, guiding the study.

\section{SYMBOLIC INTERACTIONISM AS THEORETICAL FRAMEWORK}

According to Denzin (1970) symbolic interactionism rests on three basic assumptions. Firstly, social reality as it is sensed, known and understood is a social production. Interacting individuals produce and define their own definitions of situations. Secondly, humans are assumed to be capable of engaging in "minded", self-reflexive behaviour. They have the ability to shape and guide their own behaviour and that of others. Finally, in the course of taking their own standpoint and fitting that standpoint to the behaviours of others, humans interact with one another. Interaction is seen as the emergent, negotiated and often-unpredictable concern and is symbolic because it involves the manipulation of symbols, words, meanings and languages.

The integral part of this perspective is the view that the social world of human beings is not made up of objects that have intrinsic meaning. The meaning of objects lies in the actions that human beings take towards them. Human experience is such that the process of defining objects is ever changing, subject to redefinitions, relocations and realignments. The interactionist assumes that people learn their basic symbols, their conception of the self, and the definitions they attach to social objects through interaction with others. That is, interactionists regard human interaction as their basic source of data and regard faceto-face interaction to occur in social situations.

According to Goffman's analysis in Denzin (1970, p. 5-6) it is possible to assemble the following seven features of focused interaction:

- Focused interaction involves two or more individuals taking one another's point of view.

- Interaction occurs in social settings, which can be physically located and described.

- Social objects fill social settings and will be acted on by the individuals under study.
- When taking one another's perspective, individuals use a set of rules that tacitly guide and shape their ongoing interaction; these rules may either be civil or legal in nature.

- All interaction involves persons differentially related to one another. They may be strangers, friends, colleagues, enemies or politely civil acquaintances. The total amount of time two or more individuals spend in one another's presence is termed the occasion of interaction.

- Every focused exchange between these individuals is termed an encounter. Social situations furnish the occasions of interaction, which in turn produce the condition for encounters.

- The interaction process is filtered through gendered social identities.

According to Schurink et al. (1994) symbolic interactionism emphasizes the diversity of social roles and subcultures as well as the manner in which individuals construct roles and identities through interaction with others. Interpretation, according to symbolic interactionists, is neither an autonomous act nor does a specific force determine it. People can only come to know themselves or their own social identities through the responses of others. They typically develop shared perspectives or common definitions in a given situation since they interact and share experiences, problems and backgrounds.

According to Schurink (2002, p. 13) in terms of epistemology, i.e. accepted statements justifying what the researcher believes to exist, the subject matter of his discipline/area of study, the qualitative researcher is subjective because $s /$ he interacts with the subject (object of observation). Data will be valid if the researcher does not impose his or her own ideas and preconceptions on the subjects during data collection. The epistemic imperative according to Mouton (1996, p. 28) is committed to the search for truth. He applies the term epistemic in the original Greek sense which means 'truthful or certain knowledge', in other words, knowledge that is well substantiated (as opposed to opinion) and hence provides us with an accurate representation of reality. The term 'imperative' implies a kind of 'moral contract' willingly entered into for the sake of greater good. The 'epistemic imperative' hence refers to the intrinsic moral and binding character that is inherent in the pursuit of 'truthful knowledge'. He further contends that the search for the truth is not just another option or matter of choice. Scientists who are engaged in scientific research are bound in a moral contract to commit themselves to the search for truth. Violation of this imperative implies total rejection or suspension of the notion of science, i.e. another way of saying that the terms 'science' and 'truth' are intrinsically linked. Epistemologically we attempt to capture, describe and eventually appreciate social reality, i.e. trying to gain insight into the perceptions and attitudes of one authentic former gay employee of the DOD.

We decided to select symbolic interactionism as theoretical framework for the study mainly because of the following two reasons: Firstly, this perspective is primarily concerned with people's views and interpretation of social reality. More specifically it was used in the present study to describe and capture the experiences and perceptions of one gay female former staff member of the Department of Defense. Finally, various scholars believe that this perspective is particularly appropriate to illuminate homosexuality and especially the process whereby people develop a gay identity.

In the preceding paragraphs the background to the article was sketched, the methodology was outlined, the author of the sketch was introduced and the theoretical underpinnings of the study presented. In the remainder of this article, we provide the entire sketch written by Thando for the benefit of the reader. In order to keep the article within reasonable length, our social science commentary, that is, our analysis and interpretation of Thando's story and outlining its most salient implications will be dealt with in a separate article, Part II. 


\section{FLEET OF HOPE: THANDO'S AUTOBIOGRAPHICAL SKETCH}

I tried to write a story about my life in the Defence Force, but after a paragraph or two, I realised how closely tied up my personal life including family life and my military life was.

Born into a white middle class family in 1963 in the conservative province of Transvaal, (now known as Gauteng) in Pretoria, had many advantages for a young girl in SA. I was the youngest of four children, loved and pampered by my parents and siblings. I had a normal well-adjusted home life, filled with love, humour, hope and expectations. Playing Cowboys and Indians, going on holidays with the family and enjoying the benefits of a strong family unit were an integral part of my growing up. If a negative needed to be found, I suppose being the youngest in the family by 15 years placed me in the same position as an only child. Fortunately my parents encouraged and supported me to find stimulation in various activities namely ballet, tap dancing, horse riding, tennis and a love of reading amongst many others.

\section{BACKGROUND}

Openness, honesty and transparency were part and parcel of the family tradition. Issues were discussed and cleared up before they became problems. The oldest of the siblings had decided that she wanted a child but did not want matrimony and a permanent man in her life. The family support was fantastic and she moved into my parents' home and became very close to me. My mother, being a working mother, could not always assist with schooling and all my teenage demands. My sister Grace fitted the role of surrogate mother to perfection. She was being financially supported by my parents and stayed at home to look after her daughter as well as looking after me. She moved out with her daughter 3 years later and then decided to come out of the closet and announce to all that she was indeed gay and proud of it.

I was 13 years old at that time and Grace's announcement regarding her sexual orientation changed my life dramatically. The image of a strong family unit disintegrated surprisingly fast. She was shunned as a family member and made to feel unwelcome. Siblings avoided the issue by simply ignoring her existence and when it did surface it was a passionate and heated debate. We all argued about why she had decided to be gay, how long had she been gay and how long had she been lying to us. We analysed her previous relationships and wondered which of her friends were actually lovers. The biggest fear and anger was how it was going to affect her daughter. Would she also be a social outcast, would she be ashamed of her mother and would she be able to cope? We were disappointed and outraged that she had brought this social shame on us. It was the topic of much talk amongst the wider family circle and we often bore the brunt of their laughter. For a 13 year old, innocent to the ways of the world, I felt totally betrayed by a sister who had in the past been a surrogate mother. I didn't understand the social stigmas, the fear of the other members of the family of this unknown condition or the perceived humiliation this would bring to the family. I only understood that what had happened was wrong and bad and therefore needed to be punished. This family banishment lasted for 13 years. Grace moved further and further away from the family circle and finally cut away completely when her daughter moved in with my parents.

My life continued but with maybe a little less spontaneity than before. First boyfriend at 14. I remained a virgin only because it had been ingrained in my mind by family and the conservative school I attended that pregnancy was a direct cause of intimacy. More boyfriends followed and at the age of 19, I entered into my first serious relationship with a man. We were both students and thought we had the world at our feet. It lasted 2 years. It ended when he married a girl he had got pregnant. I had really strong feelings for him; he was strong, we had a lot in common and we had planned a great future together. I don't know if that was love but I felt comfortable and safe and happy. Today I would probably describe my feelings for him as a huge learning curve. He betrayed me but I was stronger for it. My parents were great and looking back I have no feelings of regret. It was good while it lasted. Subsequently he was arrested for fraud and jailed and I was left with a feeling that I had escaped just in time.

My own social life was looking bleak after the break-up. My parents announced that they would be looking after my sister's daughter, since they felt it was more appropriate. My sister had met a woman who displayed violent tendencies and my parents felt that they could provide her daughter with a more stable environment as well as look after her financially. My sister put up no resistance. This rocked me severely and I finally understood the homophobic reaction of my family. How could a mother give up her child? It had to be because she was gay. Gay was bad, wasn't it? I actively participated in anti - homosexual discussions and debates. Voicing my opinion to anyone who cared to listen. I was the typical "verbal gay basher".

Whilst at university parties and boyfriends escalated even though I still didn't sleep with any boyfriend. Holding back because I never felt comfortable?? We were typical students. Going away for weekends partied until the early hours of the morning. We all had the odd arguments about sex. I never felt quite comfortable with having sex even though I would sleep over, cuddle and pet but never slept with a boyfriend. The fear of pregnancy still a huge factor! I also believed that I hadn't met the man of my dreams yet.

I moved out at the age of 21 and worked part time. I was getting impatient with not having money, wanting my independence. It was with the blessing of my parents that I moved into a flat with a friend. The family members remaining in the fold????, were still close but the "lost daughter" remained a silent figure. Feeble attempts were made by various family members to re-introduce Grace but no favorable results were obtained. My parents were getting older and they wanted to reconcile the family. They started visiting my sister again. She had, during that time, found her soul mate and they had been living together for many years. However, her partner was never invited to join in the family activities. This placed everybody in a lose-lose situation. We couldn't have the sister back because of her partner and she couldn't have the family back with her partner. To keep everybody half satisfied she rather maintained her distance.

The unthinkable happened at 22. I met a girl working with me Openly gay, she stood for everything I abhorred. I verbally attacked her and took any opportunity to insult her lover and friends. Despite the insults, she became a friend. The irony of the situation was that I wanted to be in her company all the time. She resigned and left for Durban. I followed her to Durban because I started to realise that perhaps I wanted to be more than just a friend. Not comfortable with the idea of perhaps being gay, I realised that I would have to follow her to find out what it was that I wanted from her. I was also terrified that the family would find out and it seemed so much easier away from the family. I believed she had to be aware of my growing feelings for her yet she never made any advances and I was becoming increasingly frustrated and confused. I was terrified but finally I made the bold move to tell her I was sexually attracted to her.

It was a time of constant questioning of myself and my new lifestyle and trying to justify why I had made the move. I believe today that the reason I was so radically anti-gay was my way of trying to convince myself that I was not "made up of the same stuff" as Grace. It was also a time of great anxiety that someone would find out about me and inform my parents. Living away from home made it so much easier though and we were partners for 2 years. We were young, in love and believed that Durban was our oyster, far away from prying eyes, insults and recriminations. We remained insular in our youthful exuberance, never meeting other straight or gay people. We were happy with each other and that seemed sufficient. It wasn't sufficient however, and the relationship ended two years later. The reason was that I couldn't come to terms with the idea that I was gay and on various occasions I set out to prove to myself 
and anybody who cared to listen that I was attractive to men as well as attracted to them. Obviously this caused many disagreements in our relationship. Perhaps, both young enough to want to experience life and all it could offer, we just drifted apart. She left South Africa, had a daughter and the last I heard, had settled down with a man in Israel. I felt totally isolated. Not quite sure about my sexuality, not sure how to handle the guilt of who I was and what I was. I couldn't speak to my family for fear of their reaction and subsequent rejection and not knowing any other gay people I was at the lowest point in my life. My sister Daisy, realising I was going through a troubled period in my life suggested I "find myself" overseas.

I transferred my sexual problems overseas still not knowing how to handle the predicament in which I found myself. Every woman I met I would assess in terms of her sexual orientation. I wanted to meet other lesbians but as it turned out I only met two, and never felt close enough to discuss my situation. I had one or two sexual encounters with men but nothing serious enough to even warrant remembering their names. After meeting my family in Greece, I felt homesick enough to return to South Africa. This was in 1986. I had made up my mind by then that I was bisexual and I possibly still would one day meet the man of my dreams, have kids and live with him forever. It just seemed the easiest way out. I believed that bisexuals were considered as young people experimenting and finding themselves. It was easy to hide behind that.

\section{CAREER}

Back home, I was pressurized into making appropriate career decisions and found myself looking at a picture of a female in uniform, graced with beauty, intelligence and style. This coupled to the general perception that many women in uniform were believed to be gay convinced me that I wanted to join the Defense Force. Still not sure of my sexuality I was not interested in joining the Army, perceiving the women to be "butch" and "undesirable" in the social context. Whatever I was and whatever I was going to be, "butch" was not an option. I had no intention of loosing my femininity, dressing up in check shirts, big buckles, men's boots and men's pants. I still wanted to believe that I could be desirable to men and even if I was boyish and lived in jeans, it did not mean looking like a man. I believed a "butch" to be the stereotype with no make-up, short-cropped hair, large and masculine.

\section{BASICS}

I applied for and was accepted as a Navy recruit and went to Basics feeling more secure than I had in a long time. I felt part of a community and I immediately made friends with a fellow recruit who was gay and who knew many of the then gay females in the Navy called Swans. I Entered a New World where drills, shining of boots, also known as "boning", and sunset had new meaning. It also brought new meaning to the word homosexuality, discrimination and frustration. I was once again placed in a world where the mere mention of the word homosexuality was frowned upon. However, this time it was not on an emotional footing as with my parents and siblings. This time it was deemed dirty, portrayed as evil and definitely not correct. For the first time in my life, I was mixing, not with just a partner but a whole group of lesbians, yet, I was feeling even more isolated because of the barriers, reservations and limitations from a homophobic military discipline. We were forced to be careful, forced to be underhanded and forced to be heterosexual.

Upon arriving in this brave new world of sailors, we were introduced to the "rights" and the "wrongs" of military life. This included, much to my surprise, an immediate and serious discussion regarding the bad elements in the SA Navy. The majority of these "bad element swans" were junior ratings, even though some of them had been in the Navy for many years but for some or other reason had always been overlooked for promotion. A small number of swans were promoted to senior rating ranks but they were placed in posts that didn't have much future. We were cautioned not to be too friendly with these "undesirable characters" as it would jeopardize any plans we had of furthering our careers as well as placing labeling us as "one of the undesirables". They were described as dangerous and manipulative - living unhealthy lifestyles - also described as only wanting to corrupt new recruits.

\section{REALITY}

Within one week after completing Basics I was brought face to face with the real intensity of the problem. Just speaking to swans that were thought to be undesirable, brought the wrath of the "Commander in Charge of Swans" down on us. Veiled threats, verbal cautions and of course the endless psychological battering of those who were different were prevalent right from the start. The irony of the whole situation was that many of these women throwing stones, were themselves deemed "possible undesirables" but due to a fear of the system, a fear of victimization and a fear of ending up in a dead end job, they attacked homosexuality with everything they had. I have to say that this was the one and only time the word "Lesbian" was ever used to my face in the SA Navy. At the time I was shocked that the word could be bandied about without much regard for the hurt it was causing. Gay seemed so much more friendly and acceptable. Today the word is much less threatening and acceptable but in the 80's it conjured up images of "total social outcasts".

Realizing for the first time in my life that I had found a group of friends within the Navy who felt the same way as I did, I was thrilled. Cape Town was a hive of active lesbianism with lesbian gatherings at pre-arranged clubs where everybody brought their own alcohol and eats, also known as "gatparties", strong bonds and many relationships were formed and broken within the group. Just being in the company of other swans made the idea of "being different" so much easier to accept. The strangest part of the whole subculture we lived in was that very few relationships were pursued with straight swans. It was an unwritten rule that the gay swans would not actively seek out and try and to convert straight swans. Perhaps this was in part due to fear of military "justice".

I was transferred to Pretoria and groomed to perform. I contributed in the only way I knew. Be professional, be smart and keep your nose clean. The gay social setup in Pretoria was very small and I initially only had contact with one Naval lesbian who introduced me to the gay scene. I was aware of other lesbians in Pretoria but life was guarded and your private life remained closed. Now and then rumours started about infidelities with male counterparts, which suited me down to the ground. The less known about my life the happier I was. (Even if he was married the attitude was - "Oh well at least she is normal and not one of those!") A rumour was started about a married senior rating and myself. The man was called in and told that if it was true, he needed to be more discreet. Had that been a woman, both the woman and I would have been fed to the wolves.

Accelerated promotions followed, due to the belief of my immediate superiors that I was a good candidate for future success. Security clearances were forever bandied about as the "gateway to heaven". If you had a confidential clearance you qualified for promotion. The first question was always "are you a lesbian and do you have lesbian friends" - Non committal answers were always sought, even to the point were you would rehearse the question with friends over and over again to answer in the appropriate manner when the dreaded question was flung your way. This was common practice. If you didn't get your clearance you were placed in a dead end job with no chance of promotion. This happened to many lesbians in the Navy. I was fortunate. I was granted a confidential clearance, valid for ten years, first time around. Being young and ambitious I was pretty sure at the time that I would not even last ten years in the Navy and would therefore never have to undergo another inquisition. I felt that there might be better opportunities in the civilian world but I didn't want to enter that world at the time. 
The most feared directorate was Intelligence and when you were summoned to see the Head, you knew your number was up. The personal life of a lesbian swan was far removed from the military day-to-day activities. Parties were always held at home and you were invited only on recommendation of trust from another lesbian swan. Clubs were deemed far too dangerous but sometimes the need to mix with "our own kind" outweighed the adrenaline rush of fear. Days afterwards you would try to be as invisible as possible to avoid the dreaded call to Intelligence. A colleague of mine was summoned a couple of days after being to a gay club and two days of accusations behind closed doors were thrown her way. She discussed the accusations with us some time later and confirmed that she had been seen by an undercover intelligence agent at the club. The undercover agent described what she had worn and what she had to drink, whom she had spoken to and what time she had left. Obviously this could not be confirmed but it was interesting to note that she was one of the first swans to be placed on the Retrenchment list.

\section{RELATIONSHIPS}

I avoided the label for quite some time, perhaps because I had an excellent working relationship with my immediate superior as well as the fact that I did not have a permanent relationship in Pretoria. I was seeing somebody in Durban but it was a mutual holiday relationship and seemed very far removed from Pretoria. However, I soon met a swan who had been transferred to Pretoria, and we really hit it off. The scary part was that she was in the intelligence division and to top it all she was straight. We spent many weeks talking, becoming firm friends. She started putting two and two together and came up with four and finally one night after our usual dancing around various issues she made a move. She asked me if I was gay and she told me she wanted to be part of my life. I actually didn't give her a straight answer but found myself on a roller coaster of emotions. I wanted her to know and I wanted her to be a part of my life. I was terrified. Even though we had mutual trust as friends, she WAS INTELLIGENCE. Could this be a scam to place me in a compromising position? She convinced me that she was not "spying" and was really interested. It is not easy to keep a secret of such magnitude when you are opening your heart to someone. However, we moved towards an intimate relationship as any heterosexual relationship would. We moved very slowly into a relationship, initially spending a weekend out of town and talking about the repercussions, the advantages and why it may not be a good idea to get involved. I also came to the conclusion that she possibly had more to lose from this relationship. I had no responsibilities. I was young with money in my pocket and a place to stay. She was a single mother who needed to pursue her career. She was granted a state owned flat but I could not move in with her, as the system did not allow for this. If you were a single mother, which she was, divorced or married you qualified for a state owned house or flat. You were not however allowed boarders. She also could not stay in the Naval accommodation, since they did not have facilities for children. This left us in a predicament. I could not live with her; she could not live with me at the Naval accommodation. The only alternative was to count the pennies and buy a property that we could share since I was not prepared to rent a place.

Living with your partner. WOW what an experience. Two wellprepared bedrooms, your clothes are in your own cupboard, except those you share with your partner. Always making sure no one knows what goes on in your life. It's lying and faking; you could never really be yourself until you closed the door of your home behind you. At the time we were probably only true to each other. Not allowing ourselves to show affection in front of her daughter, not being truthful at work about our social lives and even pretending to those in the apartments around us that I was only a visitor. Clothes were packed in separate cupboards, bedrooms were designed to show our own identities and we had to have three rooms to prove that were sleeping separately.
There were of course other problems. We could not have a combined subsidy, as we were not married. The property had to go into either her name or mine and at that time she could receive the better subsidy due to her rank and length of service. We had to get by on trust. I had no official or legal hold on the property and even a personal contract did not hold much weight. It would not prevent her from placing us in debt if she used the property as surety. Fortunately this never happened.

This led to even more obvious consequences. This was a huge move for both of us as we were really exposing ourselves. How do you really keep something like this a secret? I was living with a woman!! It had to be a gay relationship. I was out in the eyes of the Navy. Mandy was called in and cautioned about her relationship and her security clearance was placed under scrutiny. We of course denied the existence of a gay relationship vehemently citing economic reasons at the risk of her losing her subsidy. She could not receive rent from me or her subsidy would be cancelled. You reach a stage in your life when you almost say - "To hell with the consequences". We stayed together, still being discreet at work but started to be more open in the eyes of the social world around us.

\section{OFFICERS SELECTION}

Leadership positions came my way and a natural progression was to go on "Officers Selection". Physicals, psychological questionnaires and physical endurance tests known as "vasbyts" followed. When fellow candidates were asked for their choices as ideal officers based on leadership qualities, my name was on everyone's list. However, the deciding authorities had other ideas and a very polite letter of refusal was forwarded to me with a small paragraph indicating that I may apply again at a later stage. A fellow candidate from my unit (also a high achiever - also studying, also receiving good merits and appraisals and also gay) was given a letter with a proviso not to apply again.

\section{LIFE GOES ON}

Unfortunately, due to the normal pressures of life as well as added pressures of economics, military duplicity and the pressure of being homosexual in a heterosexual world, we decided to part after four years and go our separate ways. We remained friends, split our joint finances and moved on. Nothing nasty but we both felt the time had come to move on.

At the same time I also decided that it was time to face my sister Grace whom I had not communicated with for some years. Mandy and I had made tentative moves towards reconciliation with her as she lived just around the corner from us. I suppose I felt that since she was also gay there was no reason for me not to approach her. She had been seeing her daughter on the odd occasion and I felt it was the right thing to do. I met her and her life partner and we immediately felt the deep bond we had had so many years before. Compounded by the fact that we are both gay, I am happy to write that we are still very close, especially after her partner passed away. They were together for more than 15 years.

\section{RELATIONSHIP 2}

I became very friendly with a colleague who had been a victim of a homophobic Navy from way back in the early 80's. We became partners and it was probably the happiest time of my Naval life. We spent many hours together at work, finding we had so much in common. We felt a mutual attraction developing and even though we had known each other for many years within the Navy we had never really spoken to each other on a personal basis. We started doing everything together and found that our common bond of friendship gave us a good headstart in our relationship. I had found what I was looking for: An emotional stable relationship with a strong, highly respected woman, totally loyal to the Defence Force AND she loved me as fiercely as she loved life. 
She had faced many years of discrimination in the 70's and 80's. A few examples are: You could only be promoted to the next rank if you had a confidential clearance. Her promotion was kept back two years because she couldn't get a confidential clearance. The Intelligence department thought she was gay? The only way she could convince them that she was straight was to make an oath before God that she was not gay. This was really very difficult. This was serious stuff. She was lying and God knew it? Anyway the promotion must have been more important. It worried her for a very long time though.

In those years a gay woman just could not apply for officer's selection. Why? Just seeing what happened to all the other great gay women applying and not being selected prevented her from going through the same embarrassment. Having the Intelligence department investigating your private life from the day you were born, she knew there was no way that they would not find out that she was gay. Once again it is ironic to note that many of those fieldworkers investigating her were gay themselves. They all jumped out of the closet when the new government came into power. Now that is what I call being MOFFIE!!!

House break-ins were the order of the day. Weapons and jewelry never stolen! Crockery and linen always remained neatly unpacked. Photo albums were ALWAYS opened, disturbed or moved. No evidence was ever found that it was an investigation, but the feeling was that perhaps, just perhaps, "our Intelligence friends" were looking for some form of confirmation of her being gay. Although just a suspicion, the invasion of privacy was deeply felt. Your own personal mementos, letters and clothing were being touched by unknown people, perhaps being joked about and perhaps being insulted.

She frequently recalled one incident when the military decided that they would send a signal and transfer all "the gay people" to Pretoria Headquarters to ensure they could keep an eye on them. The entire gay population was up in arms. Everybody panicked (My partner was already in Pretoria at the time.) A well-known judge decided to take the military to court for drafting his daughters to Pretoria on the presumption that they were gay. (They both were!) The instruction was subsequently cancelled and everybody felt safe for a while. But many were on the gay list: Lesbians in crime. This term sort of fits the general feeling that lesbians were regarded as nothing more than criminals.

Another incident was when a well-known gay club was raided. Everybody "caught" swore under oath that they did not really know what the place was. Of course nobody believed that! Threats were made to publish names in newspapers!! Nobody knows what the actual end result was but for many weeks the newspapers were studied intensely.

Fortunately all of this never stopped her. She still loves the military is still loyal and still promotes the military to all and sundry.

\section{A NEW WORLD}

In the 90's we settled down as a married couple would. We both felt very comfortable with the fact that we were lesbians, that we had made a commitment to each other and we both found that everybody around us seemed more relaxed and accepting of our lifestyle. Subsidy procedures had changed by then and we could coown a small house and lived openly as a gay couple. Our neighbours became friends and our strong bond was the envy of all around us. We went to gay clubs with our gay friends even taking some of our straight friends along, had private parties at home with close colleagues, gay and straight. Our dogs were our children, our home our protection and our love for each other our comfort.

My parents were invited and they became regular visitors. I had always had a close relationship with them but had just kept my own private life very much apart from my family life. They never mentioned the fact that I was gay but it was evident that they were aware that I was happy. They had a good relationship with
Sarah (my lover) and they had softened their stance considerably towards my sister Grace. It is the one regret that I have that I was never able to openly discuss the matter with them, but I always had appropriate excuses. "I didn't want to disappoint them" "They were too old". "They didn't need to be involved". They had been hurt by the whole Grace saga and I didn't feel that they deserved to be hurt again. Looking back, I believe they would have completely accepted my sexual orientation but I didn't have the courage to face them with it.

After the death of both my parents and four years down the line I still have not discussed the matter with my other siblings even though they are all aware of my sexual orientation. My sister Daisy is totally homophobic and if the subject is brought up she either ignores the issue or derides it. That is the way she feels and I respect her opinion on it. My brother John is more relaxed and even though we have never openly spoken about my being gay, we will discuss homosexual issues and my homosexual friends in a very open manner. They all have their own married lives and families to contend with as well, so it is not as though my sexual orientation is a "top of mind" issue with them.

There was an unspoken openness about our relationship. We never forced ourselves or our lifestyle on anybody. We were who we were. If you didn't like it, that was fine, but we respected the fact that what you did behind closed doors was your life and we expected the same respect from others. Traditional gay roles were never established. We were equal partners drawing strengths from each other. Both worked in the garden, both did the cooking and both cleaned the house amongst other shared duties. I completed my degree, which I received after studying part time. I had majored in Communication (and will be doing my honours next year) and we actively took part in sport. We spent some time overseas on holiday. The fear of Intelligence was greatly reduced and the pressure of being gay was slowly but surely being replaced by a confidence in our relationship and ourselves. Contributing factors may have been the retirement of the feared head of intelligence, the man who was legendary amongst the gay community as the man who could end your career as easily as clicking his fingers. Soon after the introduction of the New Constitution followed which catered for homosexuals as a minority group with RIGHTS.

We were fortunate. All around us our gay friends were having relationship problems. Even some of our straight friends parted. This made our love stronger. It seemed as though everybody was caught up in the "seven year itch" syndrome. Previously strong relationships were becoming strained and partners were starting to look around for greener pastures. We were adamant this was not going to happen to us.

At work, we became known as a couple Yes, this is still in the Navy! We had a close-knit family of friends, both straight and gay. Young gay swans started asking us for advice and joining our sports team. The team, mostly gay girls, became unit-sporting heroes when we achieved. Life was good and the Navy (at least in our unit) seemed to be relaxing its views about what we were even though we were still being spoken about when attending sporting events and we were still being regarded as "those girls". When attempting to break records we were reminded, "even though we are good, we don't have to prove that we are better than men". These constant behind the back reminders stayed but we all chose to ignore it.

As stated earlier, by this time we had a strong circle of friends who were loyal and who accepted our sexual orientation. They invited us to parties and we reciprocated with invitations of our own. We openly discussed our lives with them and they did the same. Because we were so accepting of who we were, the people around us were accepting our relationship as well. We never made a big deal of it but portrayed it as a natural relationship in a different way. We were accepted and liked by straight and gay alike that knew us. However, when we needed to go to other units or military bases it was still obvious that the social stigma was alive and well. Men constantly tried to challenge us. Trying to prove to us that we could 
never be men and they were better than us. We never wanted to be men and sometimes it was just better to back down and not get into gender sensitive areas. We would assure them that it was OK. We were not trying to be better, more intelligent, and stronger - just trying to be ourselves in a world where we are all looking for our happiness. Open hostility was never present however behind our back sniggers and remarks were continuous. You tend to develop a hard shell to block out the remarks and the hurtful actions and carry on with your lives.

\section{OFFICERS SELECTION 2}

I was advised by my superior that "perhaps the time was right" to re-apply for Officers Course.

Selection was on and once again I came out with top honors. Requirements for passing were standard psychological testing, fitness tests; work related situational exams and panel discussions as well as teamwork and general observations. After discussions with my Candidate Assessment Superior (the divisional officer of the candidates), instructors as well as discussions with the psychologists I was told that I was doing far better than what was required and acceptance was but a formality. The signal (notification memo) reflecting the chosen few was faxed to Naval Headquarters and an enthusiastic supporter of mine brought the selection list to me.

During this time, an admiral received the written signal and decided to do a bit of impromptu investigation. Approaching a colleague, she was asked in a vague manner whether she would respond to a gay officer giving her orders. She replied in the negative. Need I say more? I was at no time questioned by this man yet he decided on the basis of one reply that I was not officer material. The signal that was officially released had my name inserted one line lower than the original. One line lower meant NOT ACCEPTED. At no time was any mention made as to the reasons for the non-acceptance. In fact at no stage was a letter of refusal even forwarded to me. When I questioned the officer in charge of selection he made a vague reference to the fact that no posts were available, but shortly after that two appointments were made in exactly the posts that I had requested. After confronting the female colleague she confirmed being questioned by the admiral but also commented that she would have had no problem receiving orders from a lesbian especially if she had known it was I. It is a fact that people base their perceptions on stereotypes and only after getting past the wall of bias can you start showing who you truly are and what you are capable of. In the case of lesbians you have not only the disadvantage of being a woman in a male dominated environment but also the added disadvantage of being a lesbian.

It highlighted the predicament many straight people were confronted with in the Defense Force and I suppose the whole world. Once they knew you they could deal with the sexual direction you took but they were never completely at ease with it and found it easier to look the other way when backing was required. This has nothing to do with the fact that you are a lesbian. It is a human phenomenon that people are not that eager to stand up and fight or in this case, stand up and defend. When people have to defend something that is not totally familiar to them it is easier to back off and let you face your problems alone.

The Navy had its own code of ethics. Their promotional policy was different to that of any other arm of the service and it was run in a more conventional and traditional manner. A distinct "old boys club" existed where even straight females were left out in the cold. The gay colleague who had previously applied with me and been refused, applied for the second time. Again with me. She was selected only after great pressure was applied from her direct superior. An admiral with the right stuff you might say. She left the service after nine months as an officer!!! A legal officer and friend who had heard what had happened approached me and said I should fight the selection. When you have been emotionally hammered by men on a selection panel and knowing you will be faced by a jury of the same ilk it doesn't really fill you with much hope of change. (The original selection panel had one female officer present.)

\section{SELF ESTEEM}

By this time, my self-esteem had taken a battering and I was questioning my qualities as a leader. How could I be a good leader if I am gay? Perhaps the superiors are right and I should be seen, accommodated, reluctantly accepted but definitely NOT HEARD. Subsequently I told the legal advisor not to take it further. Looking back I was probably so brainwashed into thinking "we" as lesbians would always be branded and limited career-wise by the Defense Force that I never considered the new options and new rights in our lives granted to us in the new Constitution.

At my first mustering (specialized) course, I was placed first overall including camaraderie, academics and leadership and given glowing reports from all and sundry at the Army College. My fellow Army, SAMHS and Air Force students, many of them female and many of them overtly lesbian, did well and progressed to the ranks of majors and captains. The Navy obviously didn't agree. At the time this really made me angry and to some extent I still feel that the injustice within the Navy ended many careers of people who were obvious choices within other arms of service. You were never judged on your capabilities first. You were judged on your sexual orientation, then by your capabilities. I have subsequently changed my feelings and look at it as a great loss to the Navy and not necessarily to myself.

The result of the selection changed my opinion of the Navy to some degree, but I had committed so much of my life to the Navy that I thought I would put it behind me. Life continued, perhaps not quite so willing to believe in the system and not quite so open about my lifestyle but without any major hitches. The Navy could offer me only so much in terms of promotion and soon I would be at the highest possible rank that I "was capable of". This with the prospect of at least another 25 years available to me in the Defense Force just didn't sit comfortably with me. I started looking around and weighing up my options.

\section{CIVILIAN LIFE}

I was offered a job at a media marketing company and suddenly found myself being faced with a life where I didn't have to hide my sexual orientation, lie about my partner or fear reprisals from my superiors. I did at first because I didn't feel comfortable speaking about it. I wasn't sure what the response would be and I definitely didn't know what would happen if they discovered my secret. To my great astonishment, when I finally made the disclosure it was met with blank stares of "so what?" It was almost more difficult to disclose it to people who didn't find it scary, compromising or even threatening. How could they be so okay with it when I had been led to believe for more than a decade that it was not acceptable? What made people in the Navy so narrow minded compared to civilians? The obvious deduction is that civilians are exposed to so much more, but I also believe it has to do with the environments we find ourselves in. The media is universally accepted as being more liberal and accepting. Difference doesn't mean challenge but more likely opportunity.

\section{SELF BELIEF}

My self-image had been dented more than I had thought. I was not this female/male freak who corrupted girls. I was a wholly desirable female, educated, passionate about my country and the peoples within it and with every right to hold my head up high in society. I was very fortunate that the company I worked for believed in 
"humankind", specializing in cultural diversity. This placed me in a unique situation where the colleagues I worked with were open and unbiased to all races, sexual orientation and religions. The purpose of the company was to make people of South Africa understand that it is not what we are but who we are that makes us so lucky to be part of a changing country faced with so many different people.

\section{CONCLUSION}

It was a long road of self-discovery sometimes filled with self-doubt, guilt and anxiety but it was a road that led to my current lifestyle. I am involved with a great woman who loves and cares for me as a person of the world capable of leading nations, if perhaps not Naval troops. Looking back on my life I suppose, as with all people there are things I would have wanted to be different, things I would have done differently. Perhaps I should have joined the Army or SAMHS? Perhaps I should have taken the officer selection issue further. I didn't and that is that. However the most important thing I have learnt is that we have so much to be thankful for. There are still so much that we can do that there is no time to be wasted on regrets. I am happy, I have a great partner, I own a beautiful home and have a circle of friends and a family who loves me for who I am. What more do I need?

\section{IN SUMMATION}

Looking back on my time in the military, many incidents were relayed by friends, unfortunately some unsubstantiated. Perhaps a few events were never mentioned. However, the feeling of insecurity within the military felt by all gay members was always present. The introduction of young lesbian swans changed the mood somewhat. They never felt the force of homophobia within the Defense Force and were quite happy and proud to show their sexual orientation. That seeped through the system and by the time I left, the overall mood was not fear, even though the older guard was still cautious.

Even though by far the majority of lesbians in the Defense Force had stable, mature and long relationships, this did not matter. The feeling was that you could flirt, seduce, fraternize and break marriages as long as you were "NORMAL". A straight woman could sleep around as much as she liked, but still be more highly regarded than a lesbian. As I mentioned earlier, we were judged more on our sexual orientation than on our capabilities and that was infuriating. To this day I still cannot understand the double standards.

I cannot comment on present day issues since I have been out of the Defense Force now for three years. However, in the civilian context, much is being done to improve the lot of homosexuals in South Africa, e.g. gay partners can adopt children together, the issue of legal marriages is being addressed in court at present and medical aid laws are being changed as we speak.

\section{CONCLUSION}

From Thando's sketch outlining some of her experiences during her career in the Department of Defence, we feel that we obtained valuable and rich information on female homosexuality in the country and in the South African military context specifically. Thando's experiences as a former gay woman working in the Department of Defence shed some light on the conservative attitude of South Africa's military irrespective of the rights its members have, including the right to be treated fairly irrespective of their sexual orientation. Based on Thando's account we feel it is fair to conclude that although the law of our country permits homosexuality, it is still not an acceptable orientation in South Africa and specifically the military context. Negative perceptions and attitudes still prevail and these contribute to the phenomenon that most of the homosexuals in the military are still in the closet.
It also seems reasonable to state that homosexuals are seen to be unsuitable for military service because they pose a security risk and that their presence in its units, disrupt group cohesion, morale and discipline. Heinecken (1999: p.53) state that because of homophobic sentiments, gay soldiers are unable to function effectively in the military since the heterosexual majority does not want to socialize with them, and when in position of command, homosexual soldiers fail to demand the respect of their subordinates. All these evolve around one central issue, namely: accepting homosexuals in the military will undermine military effectiveness.

However, it is important to note that most of these arguments are based on prejudice against homosexuals with no poof that their integration has undermined the operational effectiveness of the military. Currently there are no scientific evidence that homosexual people are inherently less capable of military service than heterosexual men and women. Furthermore, there is no explanation why discrimination on the basis of sexual orientation is necessary to preserve the good order, discipline and morale.

These few rather general remarks will suffice since we provide more comments in the subsequent article.

\section{REFERENCES}

Becker, H.S. 1970. Sociological work: method and substance. New York: Free Press.

Bogdan, R. 1974. Being different: the autobiography of Jane Fry. London: Wiley.

Bogdan, R.C. \& Biklen, S.K. 1992. Qualitative research for education: An introduction to theory and methods. Second edition. Needham Heights, MA: Allyn and Bacon.

Bogdan, R. \& Taylor, S.J. 1975. Introduction to qualitative research methods: A phenomenological approach to the social sciences. New York: John Wiley and Sons.

Constitution of the Republic of South Africa Act 108. 1996. Pretoria. Government Printers.

Cressey, D. Other people's money. New York: Free Press.

Denzin, N.K. 1970. The research act: A theoretical Introduction to Sociological Methods. Third edition. New Jersey: Prentice Hall, Inc.

Draft Policy on non-discrimination on the grounds of sexual orientation in the Department of Defence. 2001.

Duckitt, J.H. 1984. Attitudes of white South Africans toward homosexuality. South African Journal of Sociology. 15 (2): 89-93.

First, L. 1995. Disclosure of a son's homosexuality: a social constructionist perspective. Master of Arts. University of South Africa: Pretoria.

Gill, J. \& Johnson, P. (2002) Research Methods for managers. $3^{\text {rd }}$ ed. Thousand Oaks, CA: Sage .

Glaser, B.G. \& Strauss, A.L. 1967. The discovery of grounded theory. Chicago, Ill: Aldine.

Gevisser, M. \& Camerson, E. (Eds.). Deviant desire. Ohannesburg: Ravan Press. Pp. 209-218.

Helm, B. 1973. Deviant or variant? Some sociological perspectives on homosexuality and its subculture. In: ASSA Sociology Southern Africa. Papers from the First (sic) Congress of the Association for Sociologists in Southern Africa. Durban: The Association.

Heinecken, L. 1998. Social equality versus combat effectiveness: An institutional challenge for the military. African Security Review. 7 (6): 3-15.

Heinecken, L. 1999. The silent right: Homosexuality and the military. African Security Review. 8 (5): 43-55.

Isaacs, G. 1979a. Working with the male homosexual client: some major theoretical and clinical assumptions. Part 1. Unpublished Mater's dissertation. Cape Town: University of Cape Town.

Isaacs, G. 1979b. Crisis intervention as a form of therapy for persons with homosexual concerns: an experimental study. Unpublished Mater's dissertation. Cape Town: University of Cape Town. 
Isaacs, G. 1985. Gay oppression in South Africa: social and psychological implications. Unpublished paper presented at First National Conference on homosecuality. Gay Association of South Africa. Johannesburg, 31 May-2 June.

Isaacs, G. \& McKendrick, B. 1992. Male homosexuality in South Africa. Identity formation, culture, and crisis. Cape Town: Oxford University Press.

Joubert, D. 1974. ot dieselfde geslag: debat oor homoseksualitiet in 1968. (Brandpunte 7). Cape Town: Tafelberg.

Joubert, D, Conradie, E.L., Louw, D.J. \& Hurst, L.A. 1980. Perspektiewe op homoseksualiteit. Durbanville: Uitgewery Boshendal.

Kotze, C.G. 1975. Die aard en betekenis van die homoseksuele subkultuur. The South African Journal of Sociology, 12 :91-88.

Krouse, M. 1994. The Arista Sisters, September 1984. A personal account of army drag. In: Gevisser, M. \& Camerson, E. (Eds.). Deviant desire. Johannesburg: Ravan Press. Pp. 209-218.

Lowney, J., Winslow, R.W. \& Winslow, V. 1981. Deviant reality: Alternative world views. Second Edition. Boston: Allyn \& Bacon, Inc.

Manning, P.K. 1991. Analytic induction. In: Plummer, K. (Ed.). Symbolic interactionism. Volume II. Contemporary issues. Aldershot, Hants, England: Edward Elgar Publishing Limited. Pp. 273-183.

Miller, M. 1981. The coming out crisis of homosexuality: an affirmation of emergent identity. Unpublished Honours dissertation. Cape Town: University of Cape Town.

Mooney, L.A., Knox, D. \& Schacht, C. 1997. Understanding social problems. New York: West Publishing Co.

Plummer, K. 1983. Documents of life: An introduction to the problems and literature of a humanistic method. London: George Allen \& Unwin (Publishers) Ltd.

Plummer, K. 2001. Documents of life 2. An invitation to a critical humanism. Thousand Oaks, CA: Sage.

Redelinghuys, J.L. 1978. 'n Psigodinamiese ondersoek na die verskynsel van lesbinisme binne 'n gesinstruktuur. Ongepubliseerde M.A.verhandeling. Pretoria: Universiteit van Pretoria.

Richardson, D. \& Seidman, S. 2002. Introduction. In: Richardson, D. \& Seidman, S. (Eds.). Handbook of lesbian and gay studies. Thousand Oaks, CA: Sage. Pp.1-12.

Schurink, W.J.1979a. Seksuele misdaad. In: Lötter, J.M., Strijdom, H.G. \& Schurink, W.J. (Reds.). Eersterust: 'n Sosiologiese studie van 'n kleurling-gemeenskap. (Sexual crime in Eersterust, a coloured community). Pretoria: RGN, pp. 3-22 tot 3-22-91 (Verslag S-63).

Schurink, W.J. 1981. Gay-vroue: 'n Sosiologiese verkenning van die leefwyse van 'n aantal lesbiërs aan die hand van outobiografiese sketse. [Gay women: A sociological exploration of the lifestyle of some lesbians, based on autobiographic sketches.] Pretoria: RGN (Verslag S-74).

Schurink, W.J. 1986. Gayness: a sociological perspective. Paper delivered at Mardi Gay: GASA's Fourth Anniversary Convention, President Holiday Inn, Johannesburg, 7-11 May.
Schurink, W.J. 1988. AIDS and the gay subculture: Some sociological comments. Paper presented at the AIDS Congress. Strategies for Southern Africa. Sandton Sun, Johannesburg, 29 April - 1 May.

Schurink, W.J. 1989. Die realiteit van homoseksualisme: 'n sosiologies-kwalitatiewe ontleding. (The reality of homosexualism: a sociological-qualitative analysis.) Potchefstroom: Potchefstroomse Universiteit vir Christelike Hoër Onderwys. (Unpublished doctoral thesis.)

Schurink, W.J. 2002. The history of Dha'kar's life story. In: Schurink, W.J. Models of qualitative research. Part Two. Doctoral Programme: Leadership in Performance and Change. Department of Human Resource Management, RAU, Johannesburg. 5 April.

Schurink, W.J. et al. 1994. Prison Health Care Services: Legislation, Perception and Statistics. Pretoria: Human Sciences Research Council.

Schurink, W.J. 2001. Models of qualitative research. Part One: Lectures. Johannesburg: Department of Human Resource Management, RAU.

Schurink, W.J. 2002. Theoretical underpinnings of qualitative research: Lecture two. Johannesburg: Department of Human Resource Management, RAU.

Schurink, W.J. 2002. Capturing and storing soft data: Lecture three. Johannesburg: Department of Human Resource Management, RAU.

Schurink, W.J. 2002. Qualitative analysis: Lecture four. Johannesburg: Department of Human Resource Management, RAU.

Schurink, W.J. 2002. Brief notes on the usage of life history method in qualitative research. Johannesburg: Department of Human Resource Management, RAU.

Schurink W.J \& Schurink, E.M. 1982. The development of the gay personality. In: The Seven Ages of Man. Proceedings of a three day symposium presented by the Department of Nursing Science in collaboration with the Centre for Continuing Education of the University of Port Elizabeth. Bergvlei: Promex Plastics. Pp. 109-129.

Schurink \& Schurink, 1983. Some characteristics of the homosexual subculture as reflected by a South African gay club. Paper presented to criminology students. Johannesburg: University of the Witwatersrand.

Schurink, E. M. \& Schurink, W.J. 1990. AIDS: lay perceptions of a group of gay men. Pretoria: HSRC (Report S-187).

Shaw, C. 1966. The Jack Roller: a delinquent boy's own story. Chicago: University of Chicago Press.

Strydom, K. 1972. Die psigo-maatskaplike aspekte van homosesualiteit. Unpublished Ph.D. thesis. Cape Town: University of Cape Town.

Woolfson, L.R. 1980. Psychological androgyny and gender identity in adult homosexual and heterosexual females. Unpublished Ph.D. thesis. Pretoria: University of South Africa. 